\title{
NITROGEN ADSORPTION BY ACTIVATED CARBON SATURATED WITH FULLERENES
}

\author{
V. Grekhov, J. Kalnacs, A. Murashov, A. Vilken. \\ Institute of Physical Energetics, \\ 21 Aizkraukles Str., Riga, LV-1006, LATVIA
}

\begin{abstract}
The ability of activated coal (AC) to capture and hold fullerenes is associated with the AC pore structure and considerably differs for different ACs. To reveal the nature of the AC holding capacity, the authors studied adsorption of nitrogen by AC samples at $77 \mathrm{~K}$ after treatment by $\mathrm{C}_{60}$ fullerene. For measurements, an Autosorb-1 (Quantachrome Instrument Co., Florida, USA) device was employed. Variations in the pore size distribution are evidence for the role of $1.5-2.0 \mathrm{~nm}$ pores in the holding of fullerene C60.
\end{abstract}

\section{INTRODUCTION}

Fullerenes are one of the diversified forms of carbon nanostructures, which were discovered many years ago [1] but have attracted attention of scientists only recently [2]. The fullerenes are hollow spheroid structures consisting of several tens of carbon atoms. The most widespread fullerene contains 60 atoms and is therefore marked as $\mathrm{C}_{60}$. Higher-order fullerenes contain 70, 76, 84 and more atoms of carbon.

The most popular method for synthesis of fullerenes is based on the thermal decomposition of graphite. Among others, the graphite arc discharge has proven to be the most efficient. Usually, the arc discharge soot contains a mixture of different fullerenes $(\sim 15-20$ weight $\%$ [3]).

The most effective way of fullerene separation is based on distinguishing the solubility of different fullerenes in a number of solvents, and also on washing them from adsorbents by solvents. In our practical work, for separation of $\mathrm{C}_{60}$ from a mix of fullerenes we employed the property of activated coal (AC) to adsorb various fullerenes from solution and to put out only $\mathrm{C}_{60}$ at washing the $\mathrm{AC}$ in a definite portion of pure solvent. The AC ability to capture all fullerenes and to give back only $\mathrm{C}_{60}$ determines the productivity of work and the purity of the obtained product. This ability is associated with the AC pore structure and considerably differs for different ACs.

The present work is an attempt to find the relationship between the pore structure of AC and its holding ability for fullerenes.

\section{EXPERIMENTAL}

The fullerene soot was produced in the arc discharge of graphite electrodes in the helium atmosphere, by the technique described in [4]. The discharge soot was processed by toluene, with a mixture $(0.5 \mathrm{~g} / \mathrm{l})$ of different fullerenes in toluene obtained. For separation of $\mathrm{C}_{60}$ from other fullerenes the mixture was filtrated 
through a $1 \mathrm{~cm}$ thick AC layer. This was accompanied with full de-colorization of the solution - from auburn at the inlet to completely colourless at the outlet. A $5 \mathrm{~g}$ portion of fresh $\mathrm{AC}$ was capable of adsorbing the fullerenes contained in 0.41 of the solution. At the following stage the AC sated with fullerenes was washed by pure toluene, with the opposite process taking place - the first toluene portion washed off only $\mathrm{C}_{60}$ fullerene and had the violet colour. When the outgoing solution became colourless, the operation was stopped.

Among the available and tested activated carbons the AC conditionally denoted X3 possesses the greatest holding capacity. To reveal the nature of this capacity for X3 and its pore structure, we studied the adsorption of nitrogen by X3 samples at $77 \mathrm{~K}$ after treatment by $\mathrm{C}_{60}$ fullerene using an Autosorb-1 device (Quantachrome Instruments Co., Florida, USA).

In all figures and tables the $\mathrm{AC}$ samples without processing by fullerenes are denoted $\mathrm{X} 3$, the samples sated with fullerenes $-\mathrm{X} 3$ sat, and the samples after $\mathrm{C}_{60}$ washing in toluene $-\mathrm{X} 3$ after.

Of particular interest is the fact that subsequent washing of X3after samples in a greater volume of toluene leads to the escape of fullerene C70 and to the possibility to identify, in principle, the pores responsible for capturing this type of fullerene. Although this was beyond the scope of our present work, the methods employed by us can be applied also for higher fullerenes.

The measurements were done by a manometric technique, in the range of possible relative pressures of nitrogen from $10^{-7}$ to 1 . The minimum dose of gaseous nitrogen under normal conditions was $0.001 \mathrm{~cm}^{3}$. The establishment of equilibrium at each point took $\geq 10 \mathrm{~min}$. The level of liquid nitrogen was kept automatically. At measurements, the substance was placed into a glass ampoule with a $9 \mathrm{~mm}$ diameter. To reduce the "empty" volume, a glass rod-insert was used. The substance weight in each case was $15-16 \mathrm{mg}$. Before measuring the adsorption, the substance was heated in vacuum at temperature $250{ }^{\circ} \mathrm{C}$ for not less than 20 hours.

The processing and presentation of the results were done using the ASWin v1.55 software.

\section{RESULTS AND DISCUSSION}

In Fig. 1, the nitrogen adsorption isotherms are presented for X3 (initial), $\mathrm{X} 3$ sat (saturated with fullerenes), and X3after (washed in toluene after the fullerene treatment).

The measured isotherms are related to the type IV isotherm according to the IUPAC classification, which corresponds to layered adsorption on a porous adsorbent. The shape of hysteresis loop is related to the type H4 in this classification [5], and is indicative of condensation in narrow pores between parallel plates.

In general terms, the isotherms can be described as follows. The steep rise in a region of low relative pressures $\mathrm{P} / \mathrm{P} 0$ ( $\mathrm{P} 0$ - pressure of saturating steams at the temperature of measuring pressure $\mathrm{P}$ ) up to 0.01 is connected with filling the micro-pores $(<2 \mathrm{~nm})$ whose sizes are comparable with the size of a nitrogen molecule $(0.364 \mathrm{~nm})$. In the region approx. up to $\mathrm{P} / \mathrm{P} 0 \sim 0.4$ the main processes are the monolayer-multilayer adsorption on an adsorbent's surface and the filling of meso-pores (i.e. those in the range $2-50 \mathrm{~nm}$ ) sized $3-4 \mathrm{~nm}$ by the mechanism 


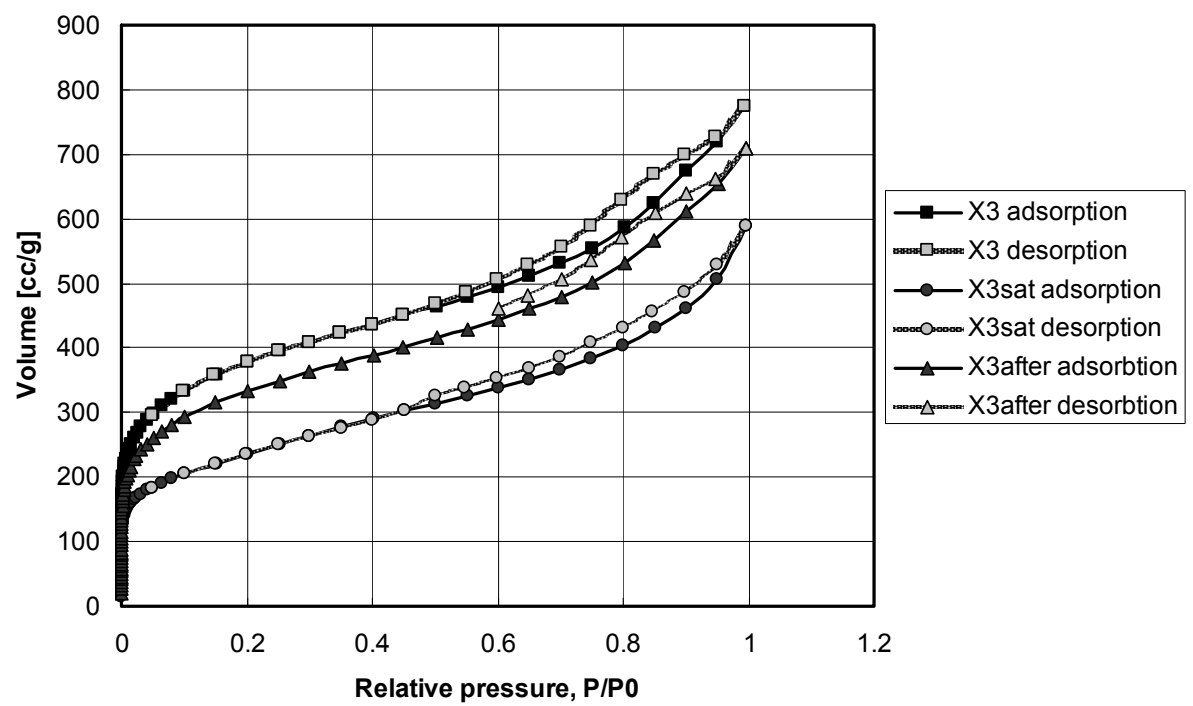

Fig. 1. The adsorption isotherms of carbon (X3). Squares - the initial carbon X3; circles - the carbon saturated with fullerenes (XSsat); triangles - the carbon washed in toluene (X3after). Black - the adsorption, grey - the desorption.

similar to that of capillary condensation. At a pressure above $0.4 \mathrm{P} / \mathrm{P} 0$, condensation in a meso-pore proceeds in compliance with Kelvin's and BJH equations [6], which is accompanied with a hysteresis loop between the adsorption and desorption branches. The authors of work [7] are of the opinion that the hysteresis starts with filling the pores of 4.4-5.8 nm size. Other authors (see, e.g. [8]) state that in the relative pressure range $0.85-0.99$ the capillary condensation occurs in aggregated pores sized from 20 to $40 \mathrm{~nm}$; such pores can form between the granules or grains of the powder.

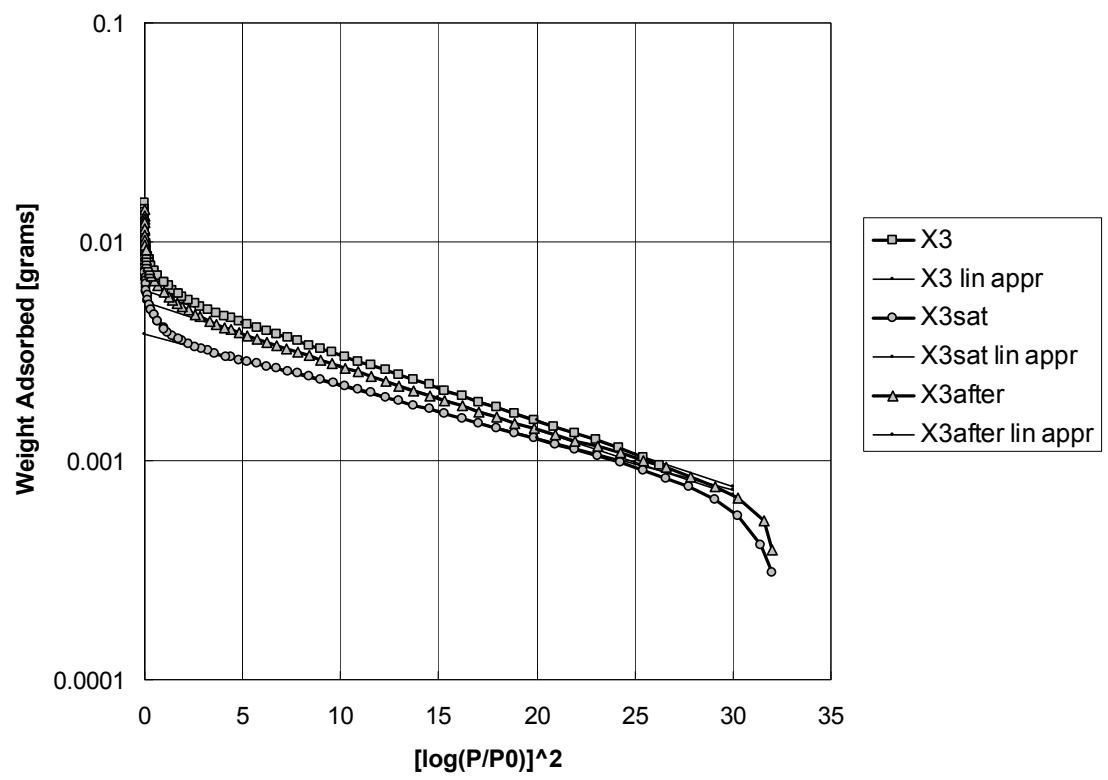

Fig. 2. Isotherms of investigated samples in the Dubinin-Radushkevich co-ordinates. Squares - the initial carbon (X3); circles - the carbon saturated with fullerenes (X3sat); triangles - the carbon washed in toluene (X3after). 
The main difference between the isotherms is observed in the region of micro-pores' filling up to the pressure of $\mathrm{P} / \mathrm{P} 0 \sim 0.01$. In this region we carried out the analysis according to the Dubinin-Radushkevich equation (DR) [9], the results of which are presented in Fig. 2 and Table 1. In the DR approach the volume filling of micro-pores is proposed. Real pores and their size distribution are replaced by pores with one average size and the related characteristic energy $\mathrm{E}_{0}$. The filled portion of the pore volume is defined by the adsorption potential as a Gaussian function.

Table 1

The Dubinin-Radushkevich approximation data

\begin{tabular}{|c|c|c|c|c|c|}
\hline Isotherms & $\begin{array}{c}\text { Approximation } \\
\text { region, } \\
\mathrm{P} / \mathrm{P} 0\end{array}$ & $\begin{array}{c}\text { Micropore } \\
\text { volume, } \\
\text { cc/g }\end{array}$ & $\begin{array}{c}\text { Average pore } \\
\text { width, } \\
\mathrm{nm}\end{array}$ & $\begin{array}{c}\text { Micropore } \\
\text { surface area, } \\
\mathrm{m}^{2} / \mathrm{g}\end{array}$ & $\begin{array}{c}\text { Adsorption } \\
\text { energy } \\
\text { (Eo), } \\
\mathrm{kJ} / \mathrm{mol}\end{array}$ \\
\hline $\mathrm{X} 3$ & $0.000016-0.016$ & $\mathbf{0 . 4 7 9}$ & 1.798 & 1347 & 14.46 \\
\hline X3sat & $0.000016-0.024$ & $\mathbf{0 . 3 0 2}$ & 1.614 & 848 & 16.11 \\
\hline X3after & $0.000040-0.015$ & $\mathbf{0 . 4 1 4}$ & 1.783 & 1161 & 14.58 \\
\hline
\end{tabular}

Decrease in the volume of micro-pores in the sample processed by X3sat fullerenes obviously occurs due to filling these micro-pores with fullerene molecules. The micro-pore surface area is obtained by recalculation of the micro-pore volume to the area of an $\mathrm{N}_{2}$ monolayer with the density of liquid nitrogen and has an illustrative character.

The specific surface $\mathrm{S}_{\mathrm{BET}}$ area is defined in the region of monolayermultilayer condensation at the relative pressures $\mathrm{P} / \mathrm{P} 0<0.3$; for $\mathrm{AC}$ this region is at $\mathrm{P} / \mathrm{P} 0<0.1$ [10], where the BET equation of isotherm [11] is valid (expressed by a straight line of the isotherm in the transformed coordinates). In Table 2 the data of BET approximation are presented.

Table 2

BET approximation data

\begin{tabular}{|c|c|c|}
\hline Isotherms & $\begin{array}{c}\text { Approximation region, } \\
\mathrm{P} / \mathrm{P} 0\end{array}$ & $\begin{array}{c}\mathrm{S}_{\mathrm{BET}} \text { area, } \\
\mathrm{m}^{2} / \mathrm{g}\end{array}$ \\
\hline X3 & $0.0158-0.151$ & $\mathbf{1 3 6 5}$ \\
\hline X3sat & $0.0194-0.202$ & $\mathbf{8 3 7}$ \\
\hline X3after & $0.0152-0.151$ & $\mathbf{1 2 0 1}$ \\
\hline
\end{tabular}

As was mentioned above, in this range of pressures the pore filling proceeds, which can lead to $S_{\mathrm{BET}}$ overestimation. The empirical methods of t- and $\alpha_{\mathrm{s}}$-plot construction allow the micro-pore filling to be distinguished from the adsorption on the external surface of an adsorbent. Both methods are based on comparison of the isotherm for the investigated porous object with that for a standard non-porous adsorbent having the same physical and chemical surface properties. In the t-plot method the adsorption (i.e. the volume of gas adsorbed under normal conditions (STP)) is plotted in dependence on the theoretical statistical thickness of the layer adsorbed on a surface [12]. The $\alpha_{\mathrm{s}}$-method was proposed by Sing [13]; according to it, the adsorption is plotted against the normalised adsorption of a standard non- 
porous adsorbent with the same surface as that of the sample under consideration. Relative pressure $\mathrm{P} / \mathrm{P} 0$ is the parameter which connects variables in both methods. In our case the t-plots were constructed versus the thickness calculated by $\mathrm{CB}$ (Carbon Black) formula [14], while as the reference isotherm for the $\alpha_{\mathrm{s}}$-method a standard isotherm "acarb" from ASWin v1.55 software was used.

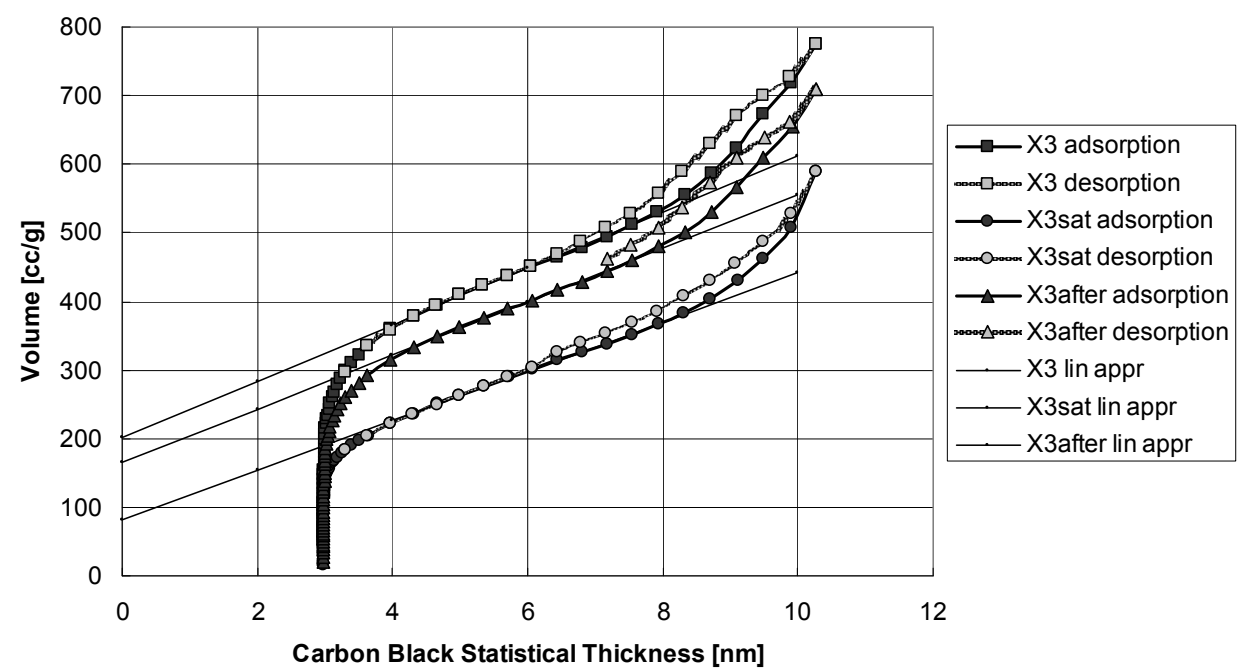

Fig. 3. Isotherms of the samples (t-plots). Squares - the initial carbon (X3); circles - the carbon saturated with fullerenes (X3sat); triangles - the carbon washed in toluene (X3after); black- adsorption, grey - desorption.

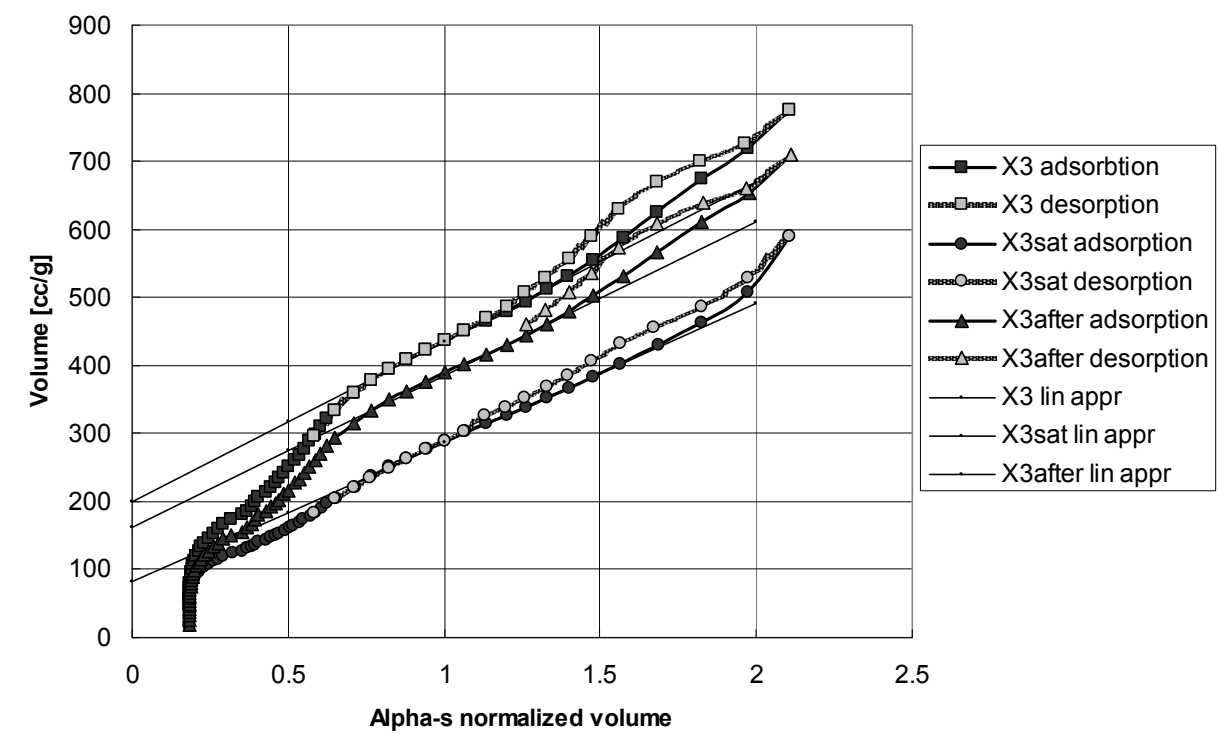

Fig. 4. Isotherms of the samples ( $\alpha_{\mathrm{s}}$-plots). Squares - the initial carbon (X3); circles - the carbon saturated with fullerenes (X3sat); triangles- the carbon washed in toluene (X3after); black- adsorption, grey - desorption.

In Figs. 3 and 4 the t- and $\alpha_{\mathrm{s}}$-plots of the isotherms under consideration are presented. The plots are similar, so if for the $\alpha_{\mathrm{s}}$-plot we recalculate the normalized volume to the thickness of the adsorbed layer (for this purpose we should know 
specific surface $\mathrm{S}_{\mathrm{BET}}$ for the reference substance) the plots become identical in the dimensions of the quantities laid on the axes. The slope of the approximating straight line has dimension $\mathrm{m}^{2} / \mathrm{g}$, and is interpreted as the specific surface of adsorption on an adsorbent's external surface that has remained free after filling the micro-pores. The intercept on the $y$-axis is the volume of gaseous nitrogen adsorbed in the micro-pores; by recalculation to the volume of liquid nitrogen we obtain the volume of micro-pores. The results of calculations are presented in Table 3.

Table 3

Volume of micro-pores and external surface of samples from t- and $\alpha_{s}$-plots

\begin{tabular}{|c|c|c|c|c|c|}
\hline \multirow{2}{*}{ Isotherms } & $\begin{array}{c}\text { Approximation } \\
\text { region, P/P0 }\end{array}$ & $\begin{array}{c}|c| \\
\mathrm{V}_{\text {MICR }} \\
\mathrm{cc} / \mathrm{g}\end{array}$ & $\begin{array}{c}\mathrm{S}_{\text {EXT }} \\
\text { area, } \\
\mathrm{m}^{2} / \mathrm{g}\end{array}$ & $\begin{array}{c}\mathrm{V}_{\text {MICR }} \\
\mathrm{cc} / \mathrm{g}\end{array}$ & $\begin{array}{c}\mathrm{S}_{\text {EXT }} \\
\text { area, } \\
\mathrm{m}^{2} / \mathrm{g}\end{array}$ \\
\hline $\mathrm{X} 3$ & $0.151-0.651$ & $\mathbf{0 . 3 1 4}$ & 633,5 & $\mathbf{0 . 3 0 8}$ & 540 \\
\hline X3sat & $0.151-0.75$ & $\mathbf{0 . 1 2 7}$ & 558 & $\mathbf{0 . 1 2 6}$ & 471 \\
\hline X3after & $0.151-0.651$ & $\mathbf{0 . 2 5 6}$ & 606 & $\mathbf{0 . 2 5}$ & 517 \\
\hline
\end{tabular}

The distribution of micro-pores in size in the region of low relative pressures can be obtained by the Horvath-Kawasoe (HK) method [15]. According to this method, the adsorption potential within slit-like micro-pores is expressed as a function of the effective pore width. The BJH method [6] based on Kelvin's equation gives the pore size distribution in the hysteresis loop region at a relative pressure $>0.35 \mathrm{P} / \mathrm{P} 0$.

The pore size distribution in a wide range can be obtained in the framework of the non-local density functional theory (NLDFT). The relevant calculation was performed using the $\mathrm{N} 2$ - carbon equilibrium transition kernel at $77 \mathrm{~K}$ based on the above mentioned slit-pore model [14]. The spectra obtained are presented in Fig. 5.

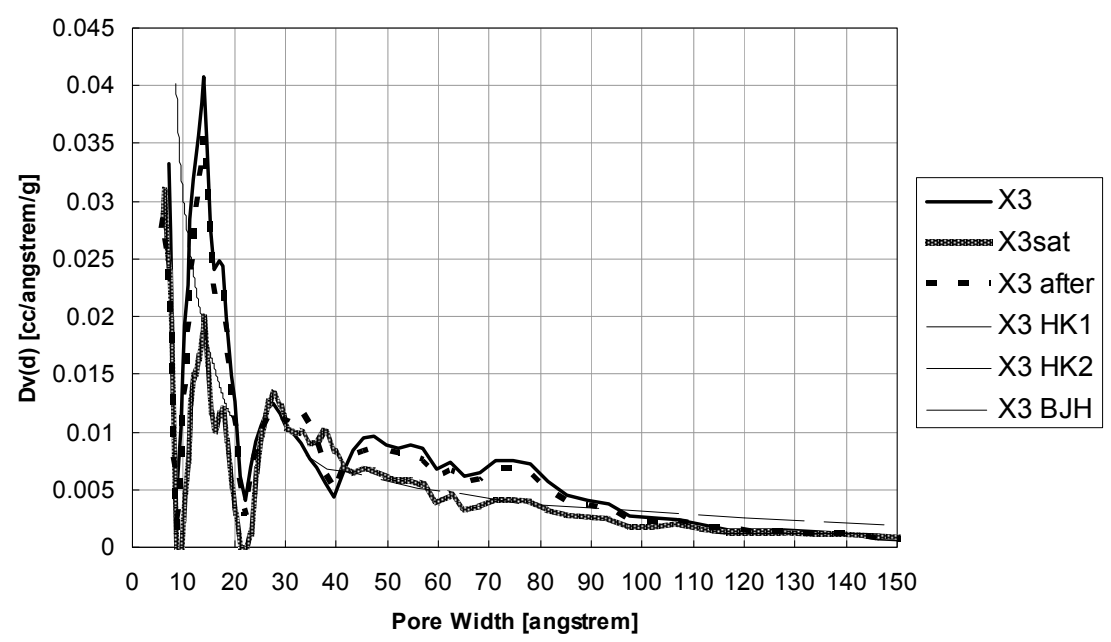

Fig. 5. The pore size distribution according to the DFT method for the initial carbon (X3), the carbon saturated with fullerenes (X3sat) and the carbon washed in toluene (X3after). 
The spectral distinctions in the pore size distribution for an adsorbent at the presence and absence of fullerenes have a steady and reproducible character. The spectra for the initial and the washed off adsorbents are quite similar: both consist of several pore groups, with their arrangement and proportions between groups remaining the same, except that the first group of pores (16 $\AA$ ) after processing became slightly less intensive, while the second group $(30 \AA)$ - somewhat wider. The spectrum for an adsorbent saturated with fullerenes differs noticeably: the first pore group becomes considerably decreased though with its shape preserved; the gap between the second and the third groups disappears, i.e. new pores arise; the rest of the spectrum is smoothed out and slightly decreased. It could be imagined that the surface has become more uniform and smooth. Note that the spectra calculated by the HK and BJH methods are similar to the NLDFT spectra by the character and numerical values (Fig. 5).

We can now estimate the volume that becomes inaccessible to the adsorption of nitrogen after processing with fullerenes as the difference between the volumes of micro-pores (Tables 1 and 3) for the initial and fullerene-saturated adsorbents (Table 4).

\section{Table 4}

Micro-pore volume difference due to fullerene processing $\left(t-, \alpha_{s^{-}}\right.$, DR approximation)

\begin{tabular}{|c|c|c|c|c|c|c|}
\hline \multirow{2}{*}{ Isotherms } & \multicolumn{2}{|c|}{$\mathrm{t}$} & \multicolumn{2}{c|}{$\alpha_{\mathrm{s}}$} & \multicolumn{2}{c|}{$\mathrm{DR}$} \\
\cline { 2 - 7 } & $\begin{array}{c}\mathrm{V}_{\text {MICR }}, \\
\mathrm{cc} / \mathrm{g}\end{array}$ & $\begin{array}{c}\mathrm{D}, \\
\mathrm{cc} / \mathrm{g}\end{array}$ & $\begin{array}{c}\mathrm{V}_{\text {MICR }} \cdot \\
\mathrm{cc} / \mathrm{g}\end{array}$ & $\begin{array}{c}\mathrm{D}, \\
\mathrm{cc} / \mathrm{g}\end{array}$ & $\begin{array}{c}\mathrm{V}_{\text {MICR }} \\
\mathrm{cc} / \mathrm{g}\end{array}$ & $\begin{array}{c}\mathrm{D}, \\
\mathrm{cc} / \mathrm{g}\end{array}$ \\
\hline $\mathrm{X} 3$ & 0.314 & $\mathbf{0 . 1 8 7}$ & 0.308 & $\mathbf{0 . 1 8 2}$ & 0.479 & $\mathbf{0 . 1 7 7}$ \\
\hline X3sat & 0.127 & & 0.126 & & 0.302 & \\
\hline
\end{tabular}

The data obtained allow estimation of the meso-pore volume as $\mathrm{V}_{0.98}$ $\mathrm{V}_{\text {MICR }}$, where $\mathrm{V}_{0.98}$ is the volume of all pores estimated by the isotherm value at $\mathrm{P} / \mathrm{P} 0=0.98$ and the meso-pore volume change at saturation with fullerenes (Table 5).

Table 5

Meso-pore volume difference due to fullerene processing (t-, $\alpha_{s^{-}}$, DR approximation)

\begin{tabular}{|l|c|c|c|c|c|c|c|c|c|c|}
\hline \multirow{2}{*}{$\begin{array}{c}\text { Iso } \\
\text { therms }\end{array}$} & \multirow{2}{*}{\begin{tabular}{l}
$\mathrm{V}_{0.98}$ \\
\cline { 3 - 12 }
\end{tabular}} & $\begin{array}{c}\mathrm{V}_{\text {MICR }} \\
\mathrm{cc} / \mathrm{g}\end{array}$ & $\begin{array}{c}\mathrm{V}_{\text {MESO }}, \\
\mathrm{cc} / \mathrm{g}\end{array}$ & $\begin{array}{c}\mathrm{D}, \\
\mathrm{cc} / \mathrm{g}\end{array}$ & $\begin{array}{c}\mathrm{V}_{\text {MICR }} \\
\mathrm{cc} / \mathrm{g}\end{array}$ & $\begin{array}{c}\mathrm{V}_{\text {MESO }}, \\
\mathrm{cc} / \mathrm{g}\end{array}$ & $\begin{array}{c}\mathrm{D}, \\
\mathrm{cc} / \mathrm{g}\end{array}$ & $\begin{array}{c}\mathrm{V}_{\text {MICR, }} \\
\mathrm{cc} / \mathrm{g}\end{array}$ & $\begin{array}{c}\mathrm{V}_{\text {MESO }}, \\
\mathrm{cc} / \mathrm{g}\end{array}$ & $\begin{array}{c}\mathrm{D}, \\
\mathrm{cc} / \mathrm{g}\end{array}$ \\
\hline $\mathrm{X} 3$ & $\mathbf{1 . 1 6 5}$ & 0.314 & $\mathbf{0 . 8 5 1}$ & $\mathbf{0 . 1 8}$ & 0.308 & $\mathbf{0 . 8 5 7}$ & $\mathbf{0 . 1 8 5}$ & 0.479 & $\mathbf{0 . 6 8 6}$ & $\mathbf{0 . 1 9}$ \\
\hline $\mathrm{X} 3$ sat & $\mathbf{0 . 7 9 8}$ & 0.127 & $\mathbf{0 . 6 7 1}$ & & 0.126 & $\mathbf{0 . 6 7 2}$ & & 0.302 & $\mathbf{0 . 4 9 6}$ & \\
\hline
\end{tabular}

\section{CONCLUSION}

Saturation of activated carbon X3 by fullerenes leads to a decrease in the nitrogen adsorption, both at the expense of reduced micro-pore and meso-pore volumes (Tables 4 and 5) and reduced external surface of the adsorbent (Table 3). The reduction in the meso-pore volume is also confirmed by the changes in the tand $\alpha_{\mathrm{s}}$-curves (Figs. 4 and 5), in the region of hysteresis. On the adsorption curves of the initial and washed X3 (Figs. 4 and 5) an appreciable rise is observed above the region of linear approximation, which corresponds to the adsorption on the 
external surface (as distinguished from the curve for the X3 saturated with fullerenes).

The main difference in the spectra of pore size distribution for adsorbents with and without fullerenes is a considerable reduction of the group with the pore size of $1.6 \mathrm{~nm}$. Variations in the pore size distribution allow for the suggestion that for holding the fullerene C60 the pores $1.5-2.0 \mathrm{~nm}$ in size are responsible. This is supported by experiments on the creation of nanotybes filled with fullerenes $\mathrm{C}_{60}$ [2], with the diameter of such fullerene-containing nanotybes being $1.4 \mathrm{~nm}$. The variations in the volume of meso-pores and the external surface of adsorbent could possibly be connected with a bottle-shaped structure of the pores.

\title{
REFERENCES
}

1. Kratschmer, W., Lamb, L., Fostiropoulos, K., \& Huffman, D. (1990). Nature, 347, 354-358.

2. Елецкий, А.В. (2004). УФН, 174, 1191-1231.

3. Song, X., Liu, Y., \& Zhu J. (2006). Carbon, 44, 1581-1616.

4. Alekseyev N. I., \& Dyuzhev, G. A. (2003). Carbon, 41, 1343-1348.

5. Schiith, F., Sing, K.S. W., \& Weitkamp, J. (ed-s). (2002). Handbook of Porous Solids. Weinheim (Germany): WILEY-VCH Verlag GmbH, 69469.

6. Barrett, E.P., Joyner, L.G., \& Halenda, P.P. (1951). J. Amer. Chem. Soc., 73, 373.

7. Ravikovich P.I., \& Neimark A.V. (2001). Colloids and Surfaces, A, 187-188, 11-12.

8. Yang Q.-H., Hou P.-X., Bai Sh., Wang M.-Z., \& Cheng H.-M. (2001). Chem. Phys. Lett., 345, 18-24.

9. Dubinin, M.M., \& Radushkevich, L.V. (1947). Dokl. Akad. Nauk. SSSR, 55, 331.

10. Sing, K. (2001). Colloids and Surfaces, 187-188, 3-9.

11. Brunauer, S., Emmett, P., \& Telle,r E. (1938). J. Amer. Chem. Soc., 60, 309.

12. Halsey G.D. (1948). J. Chem. Phys., 16, 931.

13. Sing, K.S.W. (1970). Surface Area Determination (ed-s: D.H. Everett and R.H. Ottewill), London: Butterworths, p. 25.

14. Magee, R.W. (October, 1994). Report presented at the meeting of the Rubber Division of the American Chem. Soc.

15. Horvath, G., \& Kawazoe, K. (1983). J. Chem. Eng. Japan, 16 (5), 470-475.

\section{SLĀPEKLA SORBCIJA AR AKTĪVO OGLI, KAS PIESĀTINĀTA AR FULLERĒNIEM}

\author{
V. Grehovs, J. Kalnačs, A. Murašovs, A. Viļkens. \\ Kopsavilkums
}

Ar sorbcijas iekārtu Autosorb-1 (Quantachrome Instruments Co., Florida, USA) pētîta aktīvās ogles (AO) spēja sorbēt fullerēnus no to šķ̄īuma toluolā, nosakot AO poru kopējo tilpumu un sadalījumu pēc izmēriem. Apskatītas trīs dažādas situācijas, kurās pētīta izvēlētās, fullerēnus vislabāk sorbējošās ogles spēja sorbēt slāpekli - a) kad ogle ir svaiga; b) kad tā ir maksimāli piesātināta ar fullerēnu maisījumu pie istabaas temperatūras; c) kad ogles adsorbētie fullerēni maksimāli izskaloti no ogles. Slāpekḷa sorbcija šādās atšķirīgās situācijās parāda, ka galvenā poru grupa, kas atbildīga par fullerēna $\mathrm{C}_{60}$ sorbciju ir ar poru lielumu 1.5-2.0 nm. Mazākā mērā fullerēnu sorbcija realizējas arī ar cita izmēra porām.

23.11.2010. 